\title{
Developing an understanding of race talk
}

\author{
Goodman, S. \\ Pre-print copy deposited in CURVE May 2014 \\ Original citation: \\ Goodman, S. (2014) Developing an understanding of race talk. Social and Personality \\ Psychology Compass 8 (4), 147-155 \\ DOI: \\ http://dx.doi.org/10.1111/spc3.12095
}

This is the pre-peer reviewed version of the following article: Goodman, S. (2014)

Developing an understanding of race talk. Social and Personality Psychology Compass 8 (4), 147-155, which has been published in final form at http://onlinelibrary.wiley.com/doi/10.1111/spc3.12095/abstract

Copyright $\odot$ and Moral Rights are retained by the author(s) and/ or other copyright owners. A copy can be downloaded for personal non-commercial research or study, without prior permission or charge. This item cannot be reproduced or quoted extensively from without first obtaining permission in writing from the copyright holder(s). The content must not be changed in any way or sold commercially in any format or medium without the formal permission of the copyright holders.

CURVE is the Institutional Repository for Coventry University 


\title{
Title: Developing an understanding of race talk
}

\begin{abstract}
The aim on this paper is to give an outline of the discursive psychological literature focussing on prejudice and race talk and to show how recent findings suggest a development in this understanding. The paper begins with an outline of the discursive approach and the way in which it conceptualises race talk. Next an overview of the ways in which people attempt to make prejudicial arguments so as to prevent them from appearing to be prejudiced, due to a norm against prejudice, is presented. It is then shown how challenges are being made to this norm against prejudice so that in some cases prejudice can be viewed as acceptable and in others the taboo against prejudice is presented as being discriminatory on the grounds of preventing freedom of speech and proper debate.
\end{abstract}

\section{Discursive psychology and the norm against prejudice}

Discursive psychology (DP) is the approach that argues against mainstream psychology's aim of trying to gain an understanding of what is happening in people's minds and instead claims that it is more useful and interesting to focus on what people are doing with their talk; an idea that is captured in the argument that there should be a focus on 'action, not cognition' (Edwards and Potter 1992, p. 154). The reasons for this are detailed in numerous places, and particularly by Edwards and Potter (1992) who claim that talk can never be a true representation of what people are 'really' thinking because whenever a report is made about a cognition, there is also some social action that the speaker will be attending to. So when President Obama says about raising tensions with Iran that "We believe there is still time and space to pursue a diplomatic solution and we are going to keep coordinating closely with our ... partners" (see author under review for more detailed analysis) it is not possible for us to conclude what he actually believes; instead Obama is engaged with the complicated business of international politics where he is both criticising the actions of Iran and calling on potential allies for support in any possible action against Iran. From this point of view rather than there being a problematic mismatch of attitudes and behaviour (where people may say one thing and do another) the talk is the doing. From this perspective it is in talk that people perform actions such as blaming, accounting, requesting and defending.

DP has been interested in racism for as long as it has been recognisable as a distinct area of psychology, with the seminal study 'Mapping the language of racism' (Wetherell and Potter 1992) and the theoretical 'Discursive psychology' (Edwards and Potter 1992) books both coming out in the same year. DP therefore has much to offer our understanding of racism.

From a discursive point of view there is no one given definition of racism or prejudice. Indeed Every and Augoustinos claim that:

what does and does not count as racist is a particularly salient and urgent issue for anti-racism ... however, research on representations of racism in social psychology... demonstrates that there is no single, consensual definition of racism. Rather ... there are multiple ways of defining racism and prejudice (Every and Augoustinos, 2007a, p. 414) 
They go on to argue that discursive psychologists would expect different definitions to be used for different ends. However Wetherell offers a useful definition of prejudicial talk that is based on the action orientation of the talk; that is what talk does, so for her it is any talk that 'sustains and legitimates social inequalities' (Wetherell 2003, p. 21). What this means is that while the discursive research into race and prejudice talk deals with the ways in which speakers attempt to distance themselves from being viewed as prejudiced, this talk can - and does - nevertheless still act to justify these inequalities.

Perhaps the most robust and longstanding finding of DP with regards to racism is that speakers can go to great lengths to rhetorically distance themselves from potentially being viewed as racist. This finding has been labelled the 'cultural norm against 'prejudice', (Billig 1988, p. 94). The importance of Billig's concept to the understanding of race talk cannot be overstated and it could be argued that almost all the discursive research following this has focussed on the ways that people say potentially prejudicial things in ways that do not violate this norm. Billig (1988) pointed to the ubiquitous nature of disclaimers, a feature of talk that was first described by Hewitt and Stokes (1975) in which a speaker simply denies that what is to follow is problematic with examples including 'I'm not prejudiced, because some of my best friends are Jews, but...' (Hewitt and Stokes 1975, p. 3), or a more direct 'I'm not prejudiced, but...' (Billig et al. 1988, p. 112) whereby what follows the 'but' is likely to be at least arguably hearable as prejudicial. Billig (1988) showed how this cultural norm is so widespread that it is drawn upon and referred to (or to use the DP term 'oriented to') by those who may be most expected to be accused of being prejudiced: in his study 'new racists', people purportedly with 'authoritarian' personalities (see Adorno et al 1950), anti-immigration MPs, right wing politicians and fascists. In my own research (author and author, 2013) it has been shown how the leader of the British far-right party the British National Party (BNP) suggests that there is racism in the UK but that it is not organisations such as the BNP that are racist and instead it is a white majority in the country who are the 'real' victims of racism. This provides a more recent example of someone who may be (and often is) accused of racism, drawing on the taboo against prejudice, rather than rejecting it; all in the service of denying prejudice and forwarding arguably prejudicial ideals. Perhaps the reason for the enduring nature of this cultural norm against prejudice is due to the association that prejudice has with irrationality (Billig et al, 1988; Edwards, 2003) so that speakers will go to rhetorical lengths to ensure that they are not viewed as harbouring prejudices and therefore are not irrational people.

The discursive literature on race and prejudice has now developed to such a point that Augoustinos and Every (2007a) were able to produce a review of the different strategies that have been identified as being designed to prevent speakers (or authors) from violating the norm against prejudice that Billig (1988) identified. These allow speakers to forward their position without being opened up to charges of prejudice (which can occur when the norm is broken) and the associated negative connotations of being irrational. They demonstrated that there are five strategies that are commonly used to avoid this, but which - importantly - still allow (at least arguably) prejudicial arguments to be made; that is these five strategies are the most commonly identified 'rhetorical lengths' that speakers use to provide hearably non-prejudicial reasons for their arguably prejudicial claims. The five strategies are (1) the 'denial of prejudice' (2007a, p. 125); (2) 'grounding one's views as reflecting the external world: reason 
and rationality' (2007a, p. 127); (3) 'positive self and negative other presentation' (2007a, p. 129); (4) discursive deracialisation (2007a, p. 133), and; (5) 'liberal arguments for “illiberal” ends' (2007a, p. 134). Each of these will now be addressed in turn.

\section{(1) The denial of prejudice}

The denial of prejudice is quite simply where speakers deny that what they are saying is racist. Disclaimers ("I'm not racist, but...") have been discussed above and have been shown to be an extremely common feature of race/prejudice talk (e.g. Billig et al 1988). Such denials are common not just in the talk of ordinary people but even (and perhaps especially) in the talk of those who may be most likely to be accused of racism. So, for example, the far-right British National Party leader has been shown to make denials of prejudice (e.g. "Well because we're not racist” and "They're not racist nor are we", author and author, in press). In addition to people using this strategy themselves it has also been demonstrated that the strategy is so widespread that speakers may even disclaim racism on behalf of others (Condor et al, 2006) to protect the other (and themselves by association) from potential charges of racism. van Dijk (2000) (who, it should be noted, is a discourse analyst who works from outside of the discursive psychology framework) has suggested that the use of disclaimers can create a paradox whereby the speaker simultaneously denies prejudice but in so doing draws attention to the possibility that what follows may be hearable as prejudicial. The point is supported by (the discursive psychologists) Hanson-Easey and Augoustinos, (2011) who provide an example of a disclaimer being used to signal that what follows is prejudicial.

\section{(2) The grounding of views as reflecting the external world}

By providing accounts that suggest that potentially prejudicial claims are based on the real world the speaker can be presented as rational and not prejudicial. This focus on rationality is important because, as Billig (1988) and Edwards (2003) demonstrated, prejudice is associated with irrationality. In this way speakers will draw upon any seemingly rational reasons for any claims that could potentially be viewed as prejudicial. An explicit example of this is provided by Capdevila and Callaghan (2008) who focussed on a speech by the former British Conservative party leader Michael Howard who stated that opposition to immigration is not racist but that it is 'common sense'. By focussing on common sense it is claimed that the opposition to immigration is rational. Note that in this case the strategy is used alongside a disclaimer.

\section{(3) Positive self and negative other presentation}

Another common feature of talk that could potentially be viewed as prejudicial is the inclusion of positive self presentation and negative other presentation. While a simple 'us and them distinction' is a common feature of such talk, where the ingroup is presented as favourable when compared to an outgroup (see Mehan 1997 for more on this) this distinction can also be used to present the ingroup as particularly tolerant of outgroups. The following example from Lynn and Lea's (2003) analysis illustrates how this 'us and them' distinction can be used to both distinguish in and out groups but also to present the ingroup as fair towards outgroups: 'No-one begrudges genuine refugees a home, but when bogus ones are housed within weeks ... it does seem unfair' (2003, p. 433). This strategy can work both as a denial of prejudice (on behalf 
of a whole group) and is also based in rationality, so it can be seen that these varying strategies overlap.

\section{(4)Discursive deracialisation}

Discursive deracialisation refers to the removal of race from debates that could (at least potentially) be viewed as about race. Author and author (2001), for example, focussed on the different ways that opposition to asylum in the UK, a debate that contains racial elements, is presented as being based on anything other than race. In this research economic factors, religion and terrorism, and (lack of) integration were all presented as non-racist reasons for opposing asylum. Augoustinos and Every (2007a) have suggested that issues of culture (as signalled here through religion and lack of integration) have replaced talk about race so as to achieve this discursive deracialisation; if the topic is not about race then the speaker cannot be racist.

\section{(5) Liberal arguments for" illiberal" ends}

The final strategy identified by Augoustinos and Every (2007a) is the use of supposedly liberal arguments to achieve illiberal ends. It was strategies of this nature that Wetherell and Potter (1992) focussed on in the first major discursive study to focus on race. They demonstrated how liberal arguments, such as those of treating everyone the same, are used to argue against schemes that may help underprivileged outgroups, who in their study were the native Maori of New Zealand. Another similar example of liberal meritocratic arguments being used to argue against equal rights for all can be seen in Augoustinos, Tuffin and Every's (2005) study in which they found that liberal arguments were used against equal rights for native Australian Aboriginal people.

At this point it has been demonstrated that discursive psychology offers a radical departure from traditional attitude based approaches to prejudice. Rather than viewing prejudice as something that exists in an individual's head, in discursive psychology prejudice is seen to be something that is done - or argued for - in talk. A key feature of the way in which this talk is done is to attempt to ensure that any arguably prejudicial claims are presented as anything other than based in prejudice. It has been shown that prejudice is viewed so negatively that there is a cultural taboo against it and that a number of strategies are used by speakers to avoid violating this norm.

\section{Challenging our understanding of 'prejudice'}

Discursive psychologists have convincingly argued that prejudice should be understood as something accomplished (while also being denied) in talk. However there are two important challenges that have come to light regarding this discursive work. The first is that it has been suggested that discursive psychologists, along with other psychologists, have failed to properly concentrate on what members of the public mean by prejudice and the second is that there is now growing evidence to suggest that speakers are challenging the taboo against prejudice in a way that presents it as problematic. It is these topics that will be addressed now, beginning with the problems identified with the understanding of prejudice. Figgou and Condor (2006) argued that while discursive psychologists focus on how people avoid being accused of prejudice, as demonstrated above, that they have failed to understand what it is that lay people (that is non-psychologists) understand prejudice to be, and therefore what it is that people may be attempting to distance themselves from. They 
found four lay definitions of prejudice: (1) ungrounded belief in category differences between people, (2) intolerance of group differences, (3) attributing differences to nature rather than social causes, and (4) ill feeling to low status groups from high status group members (Figgou and Condor 2006, p. 225)

A further issue with the discursive understanding of prejudice is the way in which the terms prejudice and racism are used interchangeably without due consideration of the potentially differing ways that the concepts are used. Even in Figgou and Condor's (2006) study of the way in which prejudice is understood they fail to distinguish the two. This is unsurprising given the general lack of attention to this distinction by any psychologists interested in prejudice. Key studies, including those discussed here, for example Augoustinos and Every (2007a) and Wetherell and Potter's (1992) use the terms 'prejudice' and 'racism' interchangeably.

Author and author (in press) investigated the use of these terms further after noticing people distinguishing the meanings of these words. In online discussion forums about Gypsies they found that alongside many people orienting to the cultural taboo against prejudice, others acknowledged that a position may be prejudiced, but that it is not racist. In fact it was found that a hierarchy of prejudice/racism was operating whereby racism was viewed as the most serious, and something that all speakers avoiding being associated with. Next, came prejudice which was further split into prejudice based on hearsay and prejudice based on experience. Prejudice based on hearsay, as with racism, was presented as unacceptable; indeed this type of prejudice could easily fall into the irrational type that Billig (1988) described. However it was the 'experienced based' prejudice that was presented as acceptable and that was not denied, indeed it was explicitly acknowledged; although in doing so a clear contrast with racism, which was equally explicitly denied, was made. This suggests two things, first that Gypsies represent a group towards whom prejudice is unusually acceptable (e.g. Tileaga 2006) and second that the longstanding 'cultural norm against 'prejudice”' (Billig 1988, p. 94) may be more complex than first suggested. This is not to say that there is no taboo here, as the data suggests that there is clearly a taboo against racism and some kind of taboo against prejudice; however in this example at least there is some suggestion that a limited amount of prejudice may be acceptable.

What this finding does mean is that social psychologists, including but not limited to discursive psychologists, interested in issues or racism and prejudice need to pay more attention to the distinction that may be made between prejudice and racism, and what such a distinction may be used to do. In the case of author and author (in press) it was used to position Gypsies in particularly negative ways, so it seems to be especially important to understand this for those seeking to oppose prejudice/racism.

\section{Challenges to the norm against prejudice}

By this point it has now been demonstrated that there is a cultural norm against prejudice, whereby appearing to hold prejudicial views may make a speaker look irrational, which is something to be avoided. It has also been shown that speakers use a variety of strategies to avoid appearing to violate this cultural norm, however by using these strategies speakers are still able to make claims that may function to serve prejudice. It has now been shown that the norm against prejudice may be more complicated that first anticipated, with evidence of an acceptance of prejudice 
alongside a rejection of racism. In this next section it will be shown how a new norm is developing whereby it is accusations of prejudice that have come to be problematic.

van Dijk first pointed to the idea that the term 'racism' (though not prejudice) can be seen as far too extreme to be used to account for 'modern or moderate racism' (1993, p. 180). Modern racism is a term used to describe more recent, less overt racism which is distinguished from older, more overt and violent racism (see McConahay 1986 for more on modern racism). Instead the term 'racism' tends to be saved for only the most severe and extreme cases, those more reminiscent of 'old' overt racism. This may well offer an explanation for the differentiating of racism and prejudice discussed above, but in addition to this it points to further rules surrounding talk about racism: in this case it cannot be used to describe events or comments that are deemed not serious enough. van Dijk showed that as a result, alternative terms such as 'xenophobia' or 'discrimination' are used in place of racism. An example of this can be seen in my own research. When asked about whether or not opposition to asylum seeking is racist one respondent replied 'it's possibly approaching xenophobia, but it's not racist' (author and author, 2010).

Further studies have addressed the ways in which talk about race can become problematic. Augoustinos and Every (2007b) show how accusations of racism can be responded to as particularly problematic so that it has become what they describe as a taboo against accusations of racism. To illustrate this, Every and Augoustinos (2007) demonstrate how an opponent of tight immigration control in Australia can be observed denying that he is referring to race (and therefore denying making an accusation of racism) when criticising an immigration bill. Every and Augoustinos (2007) suggest that the strategy of discursive deracialisation makes it particularly problematic for accusations of racism to be made, precisely because race has been removed from the talk.

Author (2010) analysed the ways in which opponents of asylum seeking talked about the taboo against prejudice and showed that this taboo was presented in very negative ways, particularly on the grounds of preventing freedom of speech, citing being 'pilloried' and 'smeared' for trying to tell the 'truth'. This is akin to what Lewis (2004) described as 'playing the race card' which presents accusations of racism as an unfair challenge to proper debate. This represents a serious challenge to the taboo against prejudice which, in these cases, is repositioned from something positive designed to protect against 'irrationality' to something that (irrationally) prevents debate and causes censorship. Author went on to demonstrate that within these same debates speakers could be seen to be orienting to the problems identified with the taboo against prejudice by explicitly stating that they were not trying to stifle debate, before going on to say thing that could be viewed as accusations of racism.

Author (2010) demonstrated that, in response to this, advocates of asylum seeking in the UK showed evidence of orienting to a taboo against accusations of racism in televised debates; that is any talk about race where it could be seen that accusations of racism were being made were brought about in extremely delicate ways. The examples suggest that speakers were particularly careful not to be seen as making accusations of racism precisely because of the negative connotations that are now associated with it. Further studies by Author and colleagues have demonstrated that accusations of racism (it tends to accusations of racism rather than prejudice that are 
partially problematic) are problematic because of the association they have with censorship and preventing legitimate debate in a range of different settings. These include talk by members of the public, where making accusations of racism is presented as an overly simplistic and unsophisticated way of making an argument that is not based in facts (author and author, 2010), on the social media website Facebook (author and author, 2012) and in discussions about the treatment of Gypsies (author and author, in press). This means that there is now a growing body of work that suggests that making accusations of racism have become problematic precisely because of the norm against prejudice. Further work by Every (2013) has also looked at examples of accusations of racism being made and shows how these can be largely ineffective in debates because they are easy to refute (with a simple denial). This then allows the accused to simultaneously deny being 'irrational, cowardly, spiteful and unjust' (2013, p. 680) and to articulate their own versions of what 'really; counts as racist'.

In addition to this challenge to making accusations of racism by those who are (not necessarily) direct victims of discrimination, comes the suggestion that even victims of racist attacks can downplay and remove any accusations of racism from their accounts. Evidence for this comes from Kirkwood, Mckinlay and McVittie (in press) who conducted interviews with victims of racist attacks in the UK and showed how the speakers downgraded any accusations of racism and attempted to give alternative explanations for violent attacks that appeared to have no non-racist explanation.

It does seem, therefore, that there is a growing body of work which suggests that the norm against prejudice has been challenged and as a result is in something of a state of flux. First, there is some suggestion that the norm against prejudice is not so much a norm against prejudice but a norm against racism with some kinds of prejudice viewed as acceptable and seemingly lacking a norm against it. In addition to this it has also been shown how the problems identified with making accusations of racism, associated with the norm against prejudice, have been criticised on the grounds of shutting down proper debate and being a form of censorship. The implication of this is that what once may have been a useful tool for anti-racists, accusations of racism now appear to be problematic in much the same way as being racist is. This is clearly a problem for those attempting to fight prejudice and racism. As Capdevila and Callaghan (2008, p. 12) conclude 'The effect of this anxious silence around matters of race in British politics means that it is quite possible for politicians to produce rhetoric that marginalizes and denigrates entire groups of people, without risk'. This change in the norm against prejudice therefore needs to be properly understood to prevent help prevent and fight prejudice.

\section{Conclusion: Where next?}

This paper has provided a brief overview of the discursive literature about racism. It has been shown that there is a cultural norm against prejudice which means that talk about race and prejudice is almost always made in ways that prevent the speaker from being open to suggestions of prejudice, which can make the speaker appear irrational. It has been shown that through the use of a number of different strategies speakers are able to deny prejudice while making arguments that 'sustains and legitimates social inequalities' (Wetherell 2003, p. 21). In addition to this it has also been shown that speakers may distinguish racism and prejudice so as to suggest that a certain level of 
prejudice is acceptable. It has also been shown how this norm against prejudice has been challenged for being a way of shutting down debate and preventing free speech which has forced opponents of prejudice to ensure that they avoid the negative connotations associated with making accusations of racism, by having to criticise potentially discriminatory language through alternative means.

The changing nature of the taboo against prejudice and the new ways in which those putting forward arguments that 'sustains and legitimates social inequalities'

(Wetherell 2003, p. 21) mean that new research is necessary to understand the ways in which the rules and norms around prejudice/race talk are developing. It seems that more work on the ways in which speakers define and make sense of terms and concepts such as race and prejudice as well as others such as discrimination, hate and (in)equality is needed. More work is also needed to understand the ways in which the norm against prejudice is changing, including gaining an understanding of the limits to what is (and is not) considered prejudicial and in the cases where prejudice is viewed as acceptable, the conditions that allow this to be the case. If social psychologists are to understand and fight prejudice, racism and discrimination then a better understanding of talk that justifies this is needed.

\section{References}

Adorno, T., Frenkel-Brunswick, E., Levison, D. and Stanford, R. (1950). The Authoritarian Personality. New York: Harper. [Abridged edition (1982) London: W. W. Norton and Company].

Augoustinos, M. and Every, D. (2007a). The Language of "Race” and Prejudice: A Discourse of Denial, Reason, and Liberal-practical Politics. Journal of Language and Social Psychology, 26(2), 123-41.

Augoustinos, M. \& Every, D. (2007b). Contemporary racist discourse: Taboos against racism and racist accusations. (pp. 233-254) In A. Weatherall, B. Watson \& C. Gallois (Eds.) Language, Discourse and Social Psychology. London: Palgrave Macmillan

Augoustinos, M., Tuffin, K. and Every, D. (2005). New Racism, Meritocracy and Individualism: Constraining Affirmative Action in Education. Discourse \& Society, 16(3), 315-40.

Billig, M. (1988). The Notion of "Prejudice”: Some Rhetorical and Ideological Aspects. Text, 8(1-2), 91-110.

Billig, M., Condor, S., Edwards, D., Gane, M., Middleton, D. and Radley, A. (1988). Ideological Dilemmas: A Social Psychology of Everyday Thinking. London: Sage.

Capdevila, R. and Callaghan, J. (2008). It’s not Racist. It's Common Sense”: A Critical Analysis of Political Discourse Around Asylum and Immigration in the UK. Journal of Community and Applied Social Psychology, 18, 1-16. 
Condor, S., Figgou, L., Abell, J., Gibson, S. and Stevenson, C. (2006). They're not Racist": Prejudice Mitigation and Suppression in Dialogue. British Journal of Social Psychology, 45, 441-62.

Edwards, D. (2003). Analyzing racial discourse: The discursive psychology of mindworld relationships. In H. van den Berg, M. Wetherell, M. and H. HoutkoopSteenstra, (eds.) Analyzing Race Talk: Multidisciplinary Approaches to the Interview. (pp. 31-48)Cambridge: Cambridge University Press.

Edwards, D. and Potter, J. (1992). Discursive Psychology. London: Sage.

Every, D. (2013). "Shame on you": The enactment and consequences of shame and shaming in asylum seeker advocacy. Discourse \& Society, 26(6), 1-20.

Every, D. and Augoustinos, M. (2007). Constructions of Racism in the Australian Parliamentary Debates on Asylum Seekers. Discourse \& Society, 18(4), 411-36.

Figgou, L. and Condor, S. (2006). Irrational Categorization, Natural Intolerance and Reasonable Discrimination: Lay Representations of Prejudice and Racism. British Journal of Social Psychology, 45, 219-43.

Hanson-Easey, S and Augoustinos, M. (2011). Complaining about humanitarian refugees: The role of sympathy talk in the design of complaints on talkback radio. Discourse and Communication, 5(3), 247-271.

Hewitt, J.P. and Stokes, R. (1975). Disclaimers. American Sociological Review, 40, $1-11$.

Kirkwood, S., Mckinlay, A. and McVittie, C. (in press). 'They're more than animals': Refugees' accounts of racially motivated violence. British Journal of Social Psychology. doi: 10.1111/bjso.12007

Lewis, A. (2004) . What Group?" Studying Whiteness in the Era of "Colour Blindness". Sociological Theory, 22(4), 623-46.

Lynn, N \& Lea, S. (2003). A phantom menace and the new Apartheid': the social construction of asylum-seekers in the United Kingdom. Discourse and Society, 14(4), 425-452.

McConahay, J. B. (1986). Modern Racism, Ambivalence, And the Modern Racism Scale. Prejudice, Discrimination and Racism. Dovidio, J. F. and Gaertner, S. L. (pp. 91-125). New York and Orlanso, FL: Academic Press.

Mehan, H. (1997). The discourse of the illegal immigration debate: a case study in the politics of representation. Discourse and Society, 8 (2), 249-270.

Tileaga, C. (2006). Representing the 'other': a discourse analysis of prejudice and moral exclusion in talk about Romanies. Journal of community and applied social Psychology, 16, 19-41. 
van Dijk, T. A. (2000). Parliamentary debates. In R. Wodak \& T. A. van Dijk (Eds.), Racism at the top: Parliamentary discourses on ethnic issues in six European states (pp. 45-78). Austria: Drava Verlag.

van Dijk, T. A. (1993). Elite Discourse and Racism. London: Sage.

Wetherell, M. (2003). Racism and the analysis of cultural resources in interviews. In H. van den Berg, M. Wetherell, M. and H. Houtkoop-Steenstra, (eds.) Analyzing Race Talk: Multidisciplinary Approaches to the Interview. (pp. 11-30) Cambridge:

Cambridge University Press.

Wetherell, M. and Potter, J. (1992). Mapping the Language of Racism. London: Harvester Wheatsheaf. 